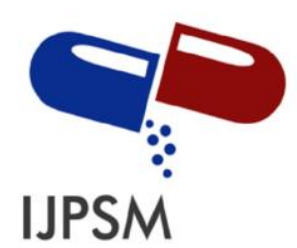

Cut Nyak Siti Ulfa Jamila et al, Int. Journal of Pharmaceutical Sciences and Medicine (IJPSM),

Vol.6 Issue. 5, May- 2021, pg. 12-20

ISSN: 2519-9889

Impact Factor: 3.426

\title{
The Ethnopharmacology, Phytochemistry, Pharmacology Activities of Yellow Velvetleaf Plant (Limnocharis flava): A Review
}

\author{
Cut Nyak Siti Ulfa Jamila ${ }^{1}$; Boy Chandra ${ }^{1}$; Zulharmita ${ }^{1}$; Harrizul Rivai ${ }^{2 *}$ \\ ${ }^{1}$ College of Pharmacy (STIFARM), Jl. Raya Siteba Kurao Pagang, Padang 25147, Indonesia \\ ${ }^{2}$ Faculty of Pharmacy, Andalas University, Limau Manih Campus, Padang 25163, Indonesia \\ "Email: harrizul@yahoo.co.id and harrizul@ phar.unand.ac.id \\ DOI: 10.47760/ijpsm.2021.v06i05.002
}

\begin{abstract}
Ethnopharmacology is a scientific study that connects a group of people, health, and the habits of the people who use traditional medicines and formulating traditional medication. The yellow velvetleaf plant is a type of plant that lives in water. This plant can be used as a vegetable for daily consumption by the community. The yellow velvetleaf plant is a plant of the Alismataceae family. This plant is ethnopharmacological, in which there is a pharmacological effect related to treatment and health maintenance for the community because it has chemical compounds such as saponins, steroids, phenol hydroquinone, and also mineral contents: Phosphorus (P), Calcium (Ca), Potassium (K), Sodium (Na), Iron (Fe), and Zinc $(\mathrm{Zn})$. This review article discusses the chemical compounds in yellow velvetleaf plants and the pharmacological effects of yellow velvetleaf plants. In this review article, it is known that yellow velvetleaf plants, used by the community as a local vegetable, have chemical compounds that can produce pharmacological effects.
\end{abstract}

Keywords: Ethnopharmacology, Phytochemistry, Pharmacological Activities, Yellow Velvetleaf

\section{Introduction}

Traditional treatment, which is carried out through medicinal plants in practice, has been practiced by the Indonesian people, especially in remote areas, since ancient times until now. It has been used in the community for treatment and health maintenance and is passed down from generation to generation. It passes the test of time and is inseparable from community life without being scientifically proven. Understanding the concept of sickness, health, and the diversity of plant species used as traditional medicine is formed through a socialization process that has been trusted and believed to be true from generation to generation [1].

Local vegetables are vegetables that can adapt to an area and grow well [2]. These plants grow naturally around the house's yard and are used as food for families. This local vegetable can also be used as a medicine whose properties are trusted from generation to generation. Consumption of local vegetables can improve public health and reduce the risk of disease [3]. Local vegetables have the potential to be developed and can overcome the problem of vitamin and nutritional deficiencies, especially for the lower-middle-class population [3]. Therefore, local vegetables are helpful as a source of vitamins, fiber, minerals, and antioxidants used by human health $[4\}$.

One of the local vegetables used by the community can be found in the yellow velvetleaf. The yellow velvetleaf plant is a plant of the Alismataceae family [5]. This plant is ethnopharmacological in which there is 


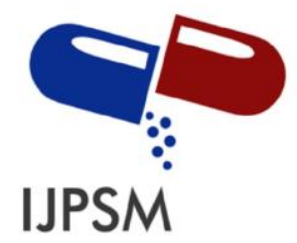

Cut Nyak Siti Ulfa Jamila et al, Int. Journal of Pharmaceutical Sciences and Medicine (IJPSM), Vol.6 Issue. 5, May- 2021, pg. 12-20

ISSN: 2519-9889

Impact Factor: 3.426

a pharmacological effect that has a relationship with treatment and health care for the community because it has chemical compounds such as saponins, steroids, phenols, hydroquinone, and mineral contents: Phosphorus (P), Calcium (Ca), Potassium (K), Sodium (Na), iron (Fe), and zinc ( $\mathrm{Zn})$ [1].

Therefore, the purpose of this review article is to obtain information from yellow velvetleaf plants that are used as local vegetables by the community for their content of chemical compounds for the treatment and health care which produces pharmacological effects.

\section{Data Collection}

The data collection method used was a literature study of national and international journals published within the last ten years period (2010-2020) connected with the ethnopharmacology of the yellow velvetleaf plants. In the making of this review article, we searched data via online media with the keywords as follows: "Ethnopharmacology," "Yellow velvetleaf," and "Limnocharis flava." The search for the primary references of this review article was carried out through trusted websites such as ScienceDirect, NCBI, ResearchGate, Google Scholar, and other trusted journal databases.

\section{Overview of Yellow Velvetleaf Plant 3.1 Description of Yellow Velvetleaf Plant}

Morphology of Yellow Velvetleaf.

All year water herb, $25-50 \mathrm{~cm}$ high.

Roots: The fibrous roots have a thick and erect rhizome, immersed in mud and brownish white.

Stem: The stem of the yellow velvetleaf plant is round. The direction of the yellow velvetleaf's branch is vertical [6], and it has an upright trunk above the ground, not woody and green.

Leaves: Single-leaf rosette-shaped roots, long stalks and perforated, soft, $15-25 \mathrm{~cm}$ long, the shape of the strands is decorated, the arrangement of the leaves is curved and parallel, tapered ends ${ }^{7}$, blunt base, flat edge, $5-50 \mathrm{~cm}$ long, wide $4-25 \mathrm{~cm}$ and green.

Flowers: Compound flowers in the form of umbrellas located in the axillary of the leaves, consisting of 3-15 buds, $15-25 \mathrm{~cm}$ long, yellow stalks. Loose petals shaped like nails, green. White, yellow 3 -stemmed stamens. The pistil is round, and the crown is open - the tip curves in yellow.

Fruit: Buni fruit, ovate, $1.5-2 \mathrm{~cm}$ in diameter, covered in green petals. Pseudo fruit with round, tiny, black seeds [5].

Yellow velvetleaf is a plant that grows wild in rice fields, swamps, or rivers, where its existence is often considered a weed [8]. The yellow velvetleaf plant is a plant of the Alismataceae family [5]. This plant has a fibrous root rhizome and has a hollow stem, and its leaves are pale green [9]. Yellow velvetleaf plants can be planted in conditions of even a little or a lot of waterlogging, and it is challenging to grow in drought conditions. Yellow velvetleaf plants are not affected by the amount of saturated, but yellow velvetleaf plants are affected by their plants and flowers by the unavailability of water [10]. The overview of the yellow velvetleaf plant can be seen in Figure 1 below. 


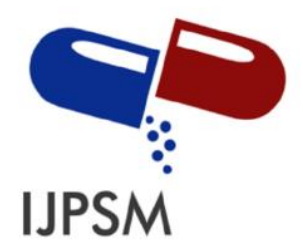

Cut Nyak Siti Ulfa Jamila et al, Int. Journal of Pharmaceutical Sciences and Medicine (IJPSM), Vol.6 Issue. 5, May- 2021, pg. 12-20

ISSN: 2519-9889

Impact Factor: 3.426

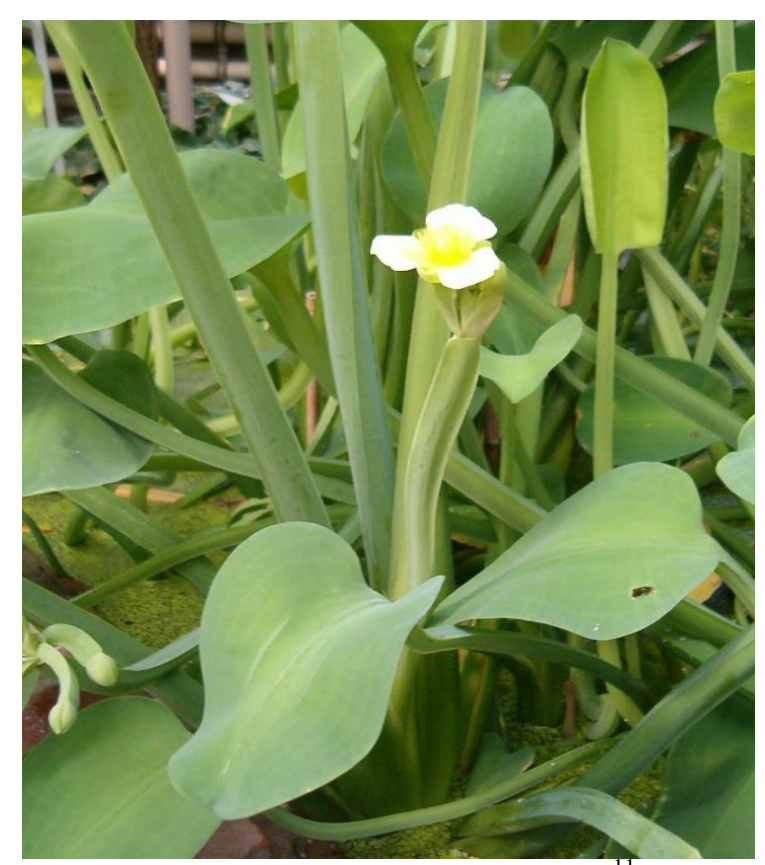

Figure 1. Yellow Velvetleaf Plant

\subsection{Classification of Yellow velvetleaf Plant [11]}

\section{Kingdom: Plantae}

Subkingdom: Tracheobionta

Superdivision: Spermatophyta

Division: Magnoliophyta

Class: Liliopsida

Subclass: Alismatidae

Order: Alismatales

Family: Alismataceae [12]

Genus: Limnocharis

Species: Limnocharis flava (L.) Buchenau

As for the naming of the yellow velvetleaf plant, it can be known by common names, such as regional and foreign names, as follows [11]:

Common Name

Indonesian $[7,11]$

Batak: Haley

Melayu: Eceng

Javanese: Genjer, Centongan

Sundanese: Gendot, Saber

Malay: Sayur Air

English: Yellow Velvetleaf 


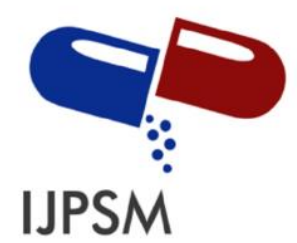

Cut Nyak Siti Ulfa Jamila et al, Int. Journal of Pharmaceutical Sciences and Medicine (IJPSM), Vol.6 Issue. 5, May- 2021, pg. 12-20

ISSN: 2519-9889

Impact Factor: 3.426

\section{Ethnopharmacology}

The yellow velvetleaf plant is a vegetable that grows in the wetland. The benefits of yellow velvetleaf plants are as follows [13]:

1. Yellow velvetleaf is helpful for people with hyperglycemia. The glucose content in yellow velvetleaf is very little, so it prevents an increase in the glycemic index.

2. Yellow velvetleaf is also beneficial for digestion because it contains fiber dissolved in water. It can relieve constipation and flatulence because the yellow velvetleaf plant is carminative.

3. Yellow velvetleaf contains a lot of beta-carotene, which in the body will be converted into vitamin A (retinol). Brick-carotene is helpful as an antioxidant that can maintain body immunity.

4. Maintain healthy skin that is often exposed to the sun, which has the potential for skin cancer

5. As a source of vitamin C. Vitamin C is an antioxidant that can protect the body from the influence of free radicals in the environment and keep the body resistant to pathogenic infections. The content of vitamin $C$ in yellow velvetleaf leaves is $54 \mathrm{mg} / 100$ grams.

6. Get rid of harmful fats. With sufficient vitamin $\mathrm{C}$ content, unhealthy fats will be bound and removed with the body's metabolic products.

7. Keep bones growing normally. It is because yellow velvetleaf plants contain lots of calcium, phosphorus, and iron. Calcium and phosphorus are macro elements necessary for bone formation ${ }^{14}$.

8. A source of phosphorus and calcium for older women, eating yellow velvetleaf is the right choice because yellow velvetleaf vegetables do not contain fat and cholesterol, which should be avoided as you enter old age.

9. Prevent anemia. Iron and vitamin A in the yellow velvetleaf plant helps to fulfill the production of red blood cells to prevent anemia.

Other Benefits of yellow velvetleaf:

Yellow velvetleaf plants have many benefits, including as an absorbent for heavy metals in the soil and as a medicine that has a lot of nutritional content [8]. Yellow velvetleaf is often used as a vegetable ingredient, especially the young leaves with unopened stalks and fruit. This plant is usually not eaten raw but heated over a fire or cooked for a short time. Processing of yellow velvetleaf as an appetite enhancer is by steaming fresh until half cooked and then consumed with other foods as lalapan. Apart from the leaves, young yellow velvetleaf flowers are also delicious for cooking. Yellow velvetleaf is suitable for stir fry, fresh vegetables, pecel, or a hodgepodge mixture. This vegetable is also rich in fiber which is good for maintaining the human digestive system tract. These vegetables can also increase appetite and are valid as animal feed [15]. There is no information on the dangers of consuming yellow velvetleaf as a vegetable or half-cooked vegetable. However, it is necessary to be careful in choosing yellow velvetleaf as food. Ensure these plants come from clean and healthy land because these plants can absorb heavy metals such as mercury, which does not dissolve in our bodies when eaten [7]. This plant can also help purify water contaminated with heavy metal waste [16]. The ethnopharmacological study is a study of plants' use by certain ethnicities used in medicine [17]. Ethnopharmacology is defined as a multidisciplinary study that studies the components of biologically active compounds used in traditional medicine. Ethnopharmacology is a scientific study that connects a group of people, health, and the habits of people who use traditional medicine and its manufacturing method. Traditional treatment is a term applied to a pre-scientific medical system. It understands medical knowledge, including books, especially official publications, containing a list of medicines with their effects and instructions for use (pharmacopeia/medicinal plants book) that have been passed down from generation to generation from healers to physician [18].

\section{Pharmacological activities \\ 5.1 Hyperglycemia}

Hyperglycemia is a medical condition in which an increase in blood glucose levels exceeds normal limits. Hyperglycemia is one of the typical signs of diabetes mellitus (DM). DM is a group of metabolic diseases characterized by hyperglycemia due to abnormalities in insulin secretion, insulin action, or both [19]. One way 


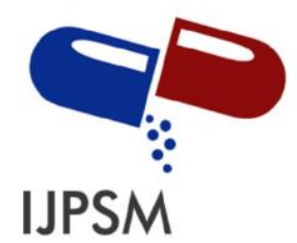

Cut Nyak Siti Ulfa Jamila et al, Int. Journal of Pharmaceutical Sciences and Medicine (IJPSM), Vol.6 Issue. 5, May- 2021, pg. 12-20

ISSN: 2519-9889

Impact Factor: 3.426

to treat or prevent this disease is by consuming yellow velvetleaf vegetables, which have very little glucose content, to avoid an increase in the glycemic index [8]. The glucose value was $2.70 \%$ in fresh yellow velvetleaf, $3.42 \%$ for 3 minutes of steaming, and $5.31 \%$ in the steaming process for 5 minutes. The value of glucose in the steamed yellow velvetleaf increased. It is presumably due to a decrease in water content and other components [20].

\subsection{Antioxidant}

The antioxidant is the activity that can delay and slow down oxidation [21]. Yellow velvetleaf, as local vegetables, have the potential as medicinal vegetables because they contain several bioactive compounds, especially antioxidants that can eliminate free radicals in body cells. Phenolic compounds are compounds that can function as antioxidants [20]. This plant is considered a weed, but on the other hand, this yellow velvetleaf plant has nutritional content [1].

The testing of free radical scavenging activity of ethanol extract and fraction of $n$-hexane, chloroform fraction, and ethyl acetate fraction of L. flava was carried out using the DPPH ABTS method. DPPH is one of the most common methods to evaluate antioxidant activity, particularly for phenol or polyphenol compounds [22]. The smaller the $\mathrm{IC}_{50}$ value, the higher the antioxidant activity. The results of the DPPH testing method by using the $\mathrm{IC}_{50}$ (Inhibition Concentration 50) parameter, which means that as much as 50\% of the sample was reduced and turned into diphenilpycrilhydrazine, which has non-radical properties. The $\mathrm{IC}_{50}$ value in fresh yellow velvetleaf was $131 \mathrm{ppm}$ [20]. This $\mathrm{IC}_{50}$ value was lower than the study by Sakong et al., which showed the total antioxidant activity of yellow velvetleaf leaves was $317 \mathrm{ppm}$ [23]. The antioxidant activity of the sample was seen from the $\mathrm{ES}_{50}$ (Effective Scavenging) value, namely the concentration of sample compounds that can capture DPPH free radicals by $50 \%$. The $\mathrm{ES}_{50}$ value obtained for gallic acid, ethanol extract, $\mathrm{n}$-hexane fraction, chloroform fraction, and L. flava ethyl acetate fraction was $208.55 ; 2,128 ; 1,117$ and $1,042 \mathrm{mg} / \mathrm{mL}$. This study concluded that the activity of gallic acid as a free radical scavenger was much greater than that of the ethanol extract, $\mathrm{n}$-hexane fraction, chloroform fraction, and ethyl acetate fraction of yellow velvetleaf [22].

The results of testing the antioxidant activity of yellow velvetleaf using the ABTS method (2,2'-azino-bis (3ethyl benzothiazoline-6-sulfonic acid) obtained values of 900,845 $\pm 20,346 \mathrm{mM}$ TEAC $/ \mathrm{g}$ dry weight. The total phenol content of yellow velvetleaf plant extracts was $14334 \pm 0.463 \mathrm{mg} \mathrm{GAE} / \mathrm{g}$ dry weight [24].

"Trolox Equivalent Antioxidant Capacity (TEAC)

*Gallic Acid Equivalent (GAE)

\section{Nutritional contents}

\subsection{Vitamin C Content}

Vitamin $\mathrm{C}$ content in yellow velvetleaf fresh is higher than after the steaming process. Its content of fresh yellow velvetleaf in dry weight was $46.63 \mathrm{mg} / 100 \mathrm{~g}$. The vitamin $\mathrm{C}$ content decreased after steaming. The value of vitamin $C$ in fresh yellow velvetleaf was $46.63 \mathrm{mg} / 100 \mathrm{~g}$, dropped after 3 minutes of cooking to 43.81 $\mathrm{mg} / 100 \mathrm{~g}$, and at 5-minute cooking, it decreased to $37.34 \mathrm{mg} / 100 \mathrm{~g}$. Steaming yellow velvetleaf for 3 minutes caused vitamin $\mathrm{C}$ levels to reduce by $6.05 \%$, and at 5 minutes, steaming decreased by $20.06 \%$. It showed that the longer the heating time causes the vitamin $\mathrm{C}$ content to fall [20].

\subsection{Vitamin $B_{1}$ Content}

Another vitamin in this yellow velvetleaf plant is Vitamin $B_{1}$ (thiamin). The levels of vitamin $B_{1}$ in fresh yellow velvetleaf plants are $0.121 \mathrm{mg} / 100 \mathrm{~g}$. The benefits of Vitamin $B_{1}$ are to treat muscle nerve disorders, such as pain, rheumatism, treatment of Vitamin $B_{1}$ deficiency diseases ${ }_{1}$, such as beriberi, fatigue, palpitations, and metabolic disorders [25]. 


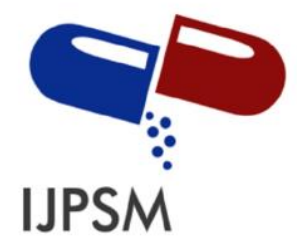

Cut Nyak Siti Ulfa Jamila et al, Int. Journal of Pharmaceutical Sciences and Medicine (IJPSM), Vol.6 Issue. 5, May- 2021, pg. 12-20

ISSN: 2519-9889

Impact Factor: 3.426

\subsection{Mineral Content}

Mineral content is a nutrient that humans need to support the growth and development process by the body in small or small amounts. The mineral content of yellow velvetleaf can be seen in Table 1 below [20].

Table 1: Mineral Content of Yellow Velvetleaf

\begin{tabular}{|c|c|c|}
\hline No. & Mineral composition & Value $(\mathrm{mg} / 100 \mathrm{~g})$ \\
\hline 1 & Phosphorus $(\mathrm{P})$ & $3,858.55 \pm 139.21$ \\
\hline 2 & Calcium $(\mathrm{Ca})$ & $1,892.25 \pm 1.86$ \\
\hline 3 & Potassium $(\mathrm{K})$ & $6,786.18 \pm 50.97$ \\
\hline 4 & Sodium $(\mathrm{Na})$ & $574.34 \pm 25.57$ \\
\hline 5 & Iron $(\mathrm{Fe})$ & $1,924.69 \pm 83.59$ \\
\hline 6 & Zinc $(\mathrm{Zn})$ & $749.48 \pm 18.19$ \\
\hline
\end{tabular}

The mineral content of the yellow velvetleaf plant stem is $16.38 \%$ greater than the leaves $12.40 \%$. The mineral contents are also related to the fiber content of the cell walls of plant tissues. The content of pectic acid can form salts in plant tissues, including calcium and magnesium. The mineral composition of the yellow velvetleaf plant is calcium, phosphorus, iron, potassium, copper, magnesium, zinc, and sodium [27].

\section{Phytochemical}

The testing of bioactive components can be done by using the phytochemical test method. Phytochemical tests for medicinal plants are needed, it is used to determine secondary metabolite compounds found in medicinal plants that are not used or required for normal body function. However, it has a beneficial effect on health or has an active role in preventing disease in the community. Yellow velvetleaf is known to contain secondary metabolites, namely tannins, quinones, polyphenolic, flavonoids, steroids/terpenoids, sesquiterpenes, and monoterpenes [26]. The results of phytochemical testing can be seen in Table 2 below [20].

Table 2: The results of testing for phytochemical content in yellow velvetleaf

\begin{tabular}{|c|c|c|c|}
\hline No. & Phytochemical Test & Reagents & Observation Results \\
\hline 1 & Steroid & $\begin{array}{c}\text { Chloroform, } \\
\text { Anhydrous acetate, } \\
\mathrm{H}_{2} \mathrm{SO}_{4} \text { sensitive } \mathrm{t}\end{array}$ & Bluish-green color \\
\hline 2 & Saponin & $\begin{array}{r}\mathrm{Hot} \text { water, } \\
\mathrm{HCl} 2 \mathrm{~N}\end{array}$ & Foam \\
\hline 3 & $\begin{array}{c}\text { Phenol } \\
\text { Hydroquinol 70\%, } \\
\mathrm{FeCl}_{3}\end{array}$ & Formed dark green \\
\hline 4 & Flavonoids & $\begin{array}{c}\text { Mg Powder, Amyl Alcohol } \\
\text { Wagner Reagent, Mayer } \\
\text { Reagent, Dragendrof Reagent }\end{array}$ & Amyl Alcohol Layer was not formed \\
\hline 5 & Alkaloid & &
\end{tabular}

The results showed that the secondary metabolites found in the leaves of yellow velvetleaf are flavonoids, phenol hydroquinone, reducing sugars, and amino acid. The stem of the yellow velvetleaf plant contains secondary metabolites in the form of flavonoids, reducing sugars, and amino acids. The components of flavonoids and reducing sugars are the main bioactive components produced by yellow velvetleaf plants [27]. The total phenolic content was $5.4 \mathrm{mg} \mathrm{GAE} / \mathrm{g}$ plants, and total flavonoids were $3.7 \mathrm{mg}$ RE/g plants [20]. 


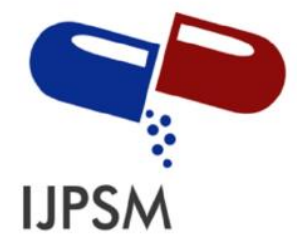

Cut Nyak Siti Ulfa Jamila et al, Int. Journal of Pharmaceutical Sciences and Medicine (IJPSM), Vol.6 Issue. 5, May- 2021, pg. 12-20

ISSN: 2519-9889

Impact Factor: 3.426

The chemical content is the chemical compound found in the yellow velvetleaf plant, which has nutritional value that can benefit public health. The following is a table of the chemical content of yellow velvetleaf plants [20].

Table 3: The Chemical Content of Yellow Velvetleaf

\begin{tabular}{|c|c|c|}
\hline No. & Chemical content & Value $(\mathrm{mg} / 100 \mathrm{~g})$ \\
\hline 1 & Moisture content & $93.92 \pm 0.13$ \\
\hline 2 & Fat content & $0.20 \pm 0.00$ \\
\hline 3 & Protein content & $2.38 \pm 0.01$ \\
\hline 4 & Ash content & $0.70 \pm 0.14$ \\
\hline 5 & Acid insoluble ash content & $0.10 \pm 0.00$ \\
\hline 6 & Crude fiber content & $1.31 \pm 0.06$ \\
\hline 7 & Glucose content & $2.70 \pm 0.00$ \\
\hline
\end{tabular}

The ash content was higher in stems than leaves. Limbs had an ash content of $38 \%$, while the leaves had as much as $12.40 \%$. The high ash content of the limbs is caused by some pectic acid and pectin acid, which forms the stem of the yellow velvetleaf plant [27]. High levels of ash can be caused by the high mineral content and soil and water where the plant grows [22]. The fat content in the leaves of the yellow velvetleaf plant is higher than that of the yellow velvetleaf plant. The fat content in the leaves in dry conditions was $7.95 \%$, while in the stem, it was $5.62 \%$. It is because glycolipid is the main component of the yellow velvetleaf plant leaf membrane [27]. The protein content is also higher in the leaves of the yellow velvetleaf plant than in the stems of the yellow velvetleaf plant. The protein in the leaves of yellow velvetleaf was $22.9 \%$, while the limbs were $13.23 \%$ in dry condition. The amount of protein content in yellow velvetleaf leaves is due to many chloroplasts in the leaves [27]. The fiber content in standard yellow velvetleaf stems was $16.12 \%$, while in leaf was $11.93 \%$. The fiber content in the yellow velvetleaf stems is caused by the growth of the yellow velvetleaf stems resulting in a build-up of fibers in the limbs [27]. Fiber is needed to help digestion so that the digestive process can work optimally [28]. The fiber content is primarily found in the stem of the yellow velvetleaf plant compared to the leaves. It indicates that the total carotene content is higher in the leaves than in the limbs [27]. The results of the journal review study found that there were $219.01 \mu \mathrm{g} / \mathrm{g}$ carotenoids in the leaves of the fresh yellow velvetleaf plant and $92.99 \mu \mathrm{g} / \mathrm{g}$ in the stems - many in the leaves which cause dark green leaf color [29]. The beta-carotene content in yellow velvetleaf plants can decrease due to the steaming process during processing [20]. Yellow velvetleaf leaves and flowers contain high enough fiber (1.56\% and $1.42 \%)$, protein (2.04\% and $1.98 \%)$, and carbohydrates $(3.16 \%$ and $2.98 \%)$. The amino acid analysis results showed that yellow velvetleaf leaves and flowers contained nine types of essential amino acids and eight non-essential amino acids [30].

\section{Conclusion}

An ethnopharmacology review of Yellow Velvetleaf (Limnocharis Flava) plants found that the plant is a type of local vegetable whose benefits are rarely known by the public. This plant contains phytochemicals and nutritional compounds that can be beneficial to health. This plant has pharmacological activity as antihyperglycemic and antioxidant. Therefore, this plant has the potency to develop as phytopharmaca. 


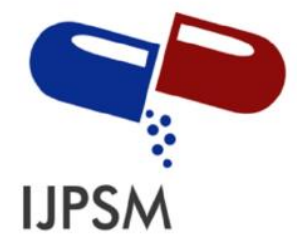

Cut Nyak Siti Ulfa Jamila et al, Int. Journal of Pharmaceutical Sciences and Medicine (IJPSM), Vol.6 Issue. 5, May- 2021, pg. 12-20

ISSN: 2519-9889

Impact Factor: 3.426

\section{References}

[1]. Mulyani Y, Sumarna R, Patonah. Kajian Etnofarmakologi Pemanfaatan Tanaman Obat Oleh Masyarakat Di Kecamatan Dawuan Kabupaten Subang Provinsi Jawa Barat. J Farm Galen (Galenika J Pharmacy). 2020;6(1):37-54. doi:10.22487/j24428744.2020.v6.i1.14106

[2]. Wiryono, Nurliana S. Dominansi Jenis-Jenis Tanaman Sayur Introduksi di Pasar Sayuran Kota Bengkulu Wiryono. 2019;8(26):181-191.

[3]. Setiawan E. Studi Etnobotani Pemanfaatan Tanaman Sayuran di Kabupaten Pamekasan. Rekayasa. 2017;10(1):1-8. doi:10.21107/rekayasa.v10i1.3614

[4]. Susanti H. Studi Etnobotani Sayuran Lokal Khas Rawa Di Pasar Martapura Kalimantan Selatan. Ziraa'ah. 2015;40(2):140-144 140.

[5]. Direktorat Jendral Kefarmasian dan Alat Kesehatan KKR. Acuan Bahan Baku Obat Tradisional Dari Tumbuhan Obat Di Indonesia.; 2017.

[6]. Isa I, Jahja M, Sakakibara M. Potensi Tanaman Genjer (Lamncharis Flava) Sebagai Akumulator Logam $\mathrm{Pb}$ dan $\mathrm{Cu}$. Skripsi. 2010;(6):1-38.

[7]. Hidayat S, Napitupulu RM. Kitab Tumbuhan Obat. (Nurrohmah FA, ed.). AgriFlo (Penebar Swadaya Grup); 2015. https://books.google.co.id/books?id=vQLLCgAAQBAJ\&pg=PA137\&dq=tumbuhan+genjer\&hl=id\&sa=X\&ved=2ah UKEwiVnoWdnZ3uAhVu4nMBHcUSAaoQ6AEwAXoECAQQAg\#v=twopage\&q=tumbuhan genjer\&f=false

[8]. Chaidir L, Yuliani K, Taufik F. Di Kabupaten Pangandaran Berdasarkan Karakter Morfologi Dan Agronomi Exploration and Characterization Of Genjer (Limnocharis flava (L.) Buch) In Pangandaran Regency Based On Morphology and Agronomic Characters. 2016;III(2):53-66.

[9]. Abhilash PC, Pandey VC, Srivastava P, et al. Phytofiltration of cadmium from water by Limnocharis Flava (L.) Buchenau grown in free-floating culture system. J Hazard Mater. 2009;170(2-3):791-797. doi:10.1016/j.jhazmat.2009.05.035

[10]. Ranawakage VP, Ellawala KC, Chaminda GGT. Preliminary study on the influence of water level on the growth and morphology of Limnocharis Flava (L.) Buchenau. Ann Limnol. 2013;49(4):249-254. doi:10.1051/limn/2013058

[11]. Plantamor. GENJER [JW] (Limnocharis flava). Accessed December $12, \quad 2020$. http://plantamor.com/species/info/limnocharis/flava

[12]. Uddin MZ, Pal JC. Preliminary taxonomic survey of aquatic plants of Feni district, Bangladesh. Bangladesh J Plant Taxon. 2020;27(1):103-111. doi:10.3329/bjpt.v27i1.47572

[13]. Lingga L. Cerdas Memilih Sayuran. PT Agro Media Pustaka; 2010.

[14]. Fitmawati, Juliantari E, eds. Tanaman Obat dari Semak Menjadi Obat. UR Press; 2017.

[15]. Nion YA, Jemi R, Jagau Y, et al. Potensi Sayur Organik Lokal Daerah Rawa Di Kalimantan Tengah: "Manfaat dan Tingkat Kesukaan.” EnviroScienteae. 2018;14(3):259. doi:10.20527/es.v14i3.5698

[16]. Alikasturi AS, Zarith M, Mohamed A, et al. ScienceDirect Phytoremediation of Copper in Mineral, Distilled and Surface Water using Limnocharis Flava plant. Mater Today Proc. 2019;19:1489-1496. doi:10.1016/j.matpr.2019.11.173

$\begin{array}{llllll}\text { [17]. Jannah } & \text { M. } & \text { Miftahul } & \text { Jannah. } & \text { Published } & \text { online }\end{array} 2$ http://eprints.undip.ac.id/32607/1/404_MIFTAHUL_JANNAH_G2C007046.pdf

[18]. Saroya AS. Herbalism, Phytochemistry And. Science Publishers; 2011.

[19]. Soelistijo S, Novida H, Rudijanto A, et al. Konsesus Pengelolaan dan Pencegahan Diabetes Melitus Tipe 2 di Indonesia 2015.; 2015. https://www.google.com/url?sa=t\&source=web\&rct=j\&url=https://pbperkeni.or.id/wpcontent/uploads/2019/01/4.-Konsensus-Pengelolaan-dan-Pencegahan-Diabetes-melitus-tipe-2-di-IndonesiaPERKENI-2015.pdf\&ved=2ahUKEwjy8KOs8cfoAhXCb30KHQb1Ck0QFjADegQIBhAB\&usg=AOv

[20]. Nurjanah, Jacoeb AM, Nugraha R, Permatasari M, Sejati TKA. Perubahan Komposisi Kimia, Aktivitas Antioksidan, Vitamin C dan Mineral Tanaman Genjer (Limnocharis flava) Akibat Pengukusan. ajie. 2014;3(3):185-195. doi:10.20885/ajie.vol3.iss3.art3

[21]. Wijaya H, Junaidi L. Antioksidan: mekanisme kerja dan fungsinya dalam tubuh manusia. J Agro-Base Ind. 2011;28(2):44-55.

[22]. Narwanti I, Hamida IA. Uji Aktivitas Antioksidan Fraksi N-Heksana, Kloroform dan Etil Asetat Ekstrak Etanol Limnocharis flava Dengan Metode DPPH. J Insa Farm Indones. 2018;1(2):251-259.

[23]. Sakong P, Khampitak T, Cha'on U, et al. Antioxidant activity and bioactive phytochemical contents of traditional medicinal plants in Northeast Thailand. J Med Plant Res. 2011;5(31):6822-6831. doi:10.5897/JMPR11.1222

[24]. Stewart P, Boonsiri P, Puthong S, Rojpibulstit P. Antioxidant activity and ultrastructural changes in gastric cancer 


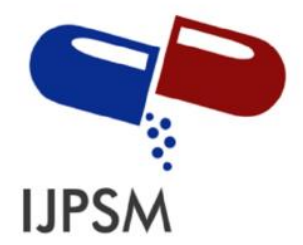
Cut Nyak Siti Ulfa Jamila et al, Int. Journal of Pharmaceutical Sciences and Medicine (IJPSM),
Vol.6 Issue. 5, May- 2021, pg. 12-20

ISSN: 2519-9889

Impact Factor: 3.426

cell lines induced by Northeastern Thai edible folk plant extracts. BMC Complement Altern Med. 2013;13. doi:10.1186/1472-6882-13-60

[25]. Rahmawati PZ, Sa'diyah DC. Penetapan Kadar Vitamin B1 Pada Genjer (Limnocharis flava) Dengan Pengukusan Menggunakan Spektrofotometer UV-VIS. J Muhammadiyah Med Lab Technol. 2020;3(2):1-10.

[26]. Prasadhana ER, Arumsari A, Kurniaty N. Uji Aktivitas Antibakteri Ekstrak Etanol Tanaman Genjer (Limnocharis flava (L.) Buchenau) Terhadap Bakteri Escherichia coli dan Bacillus subtilis. 2019;5. doi:http://dx.doi.org/10.29313/.v0i0

[27]. Jacoeb AM, Abdullah A, Rusydi R. Karakteristik Mikroskopis Dan Komponen Bioaktif Tanaman Genjer (Limnocharis Flava) Dari Situ Gede Bogor. Akuatik-Jurnal Sumber Daya Perairan. 2010;4(1):76-99.

[28]. Husni P, Fadhiilah ML, Hasanah U. Formulasi Dan Uji Stabilitas Fisik Granul Instan Serbuk Kering Tangkai Genjer (Limnocharis Flava (L.) Buchenau.) Sebagai Suplemen Penambah Serat. J Ilm Farm Farmasyifa. 2020;3(1):1-8. doi:10.29313/jiff.v3i1.5163

[29]. Rusydi R. Potential of yellow velvetleaf (Limnocharis Flava) as a protein source for fish feed Potensi. Acta Aquat. 2014;1(1):36-38.

[30]. Juhaeti T. Respon Genjer \{Limnocharis flava (L.) Buchenau.\} terhadap Pemupukan dan Potensi Gizinya untuk Diversifikasi Konsumsi Sayuran. Ber Biol. 2013;12(1):107-116.

\section{A Brief Author Biography}

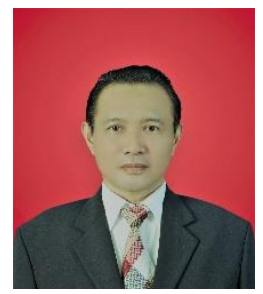

Prof. Dr. Harrizul Rivai, M.S., was born in Payakumbuh, West Sumatra, on 4 September 1953. His father is Rivai Said, and his mother is Saridahanum Syofyan. The Author obtained a Bachelor of Pharmacy from the Department of Pharmacy, Faculty of Mathematics and Natural Sciences, Padjajaran University, Bandung (1976), a Master of Science degree from the Bandung Institute of Technology (1984), and a Doctorate from the Department of Chemistry, Faculty of Mathematics and Natural Sciences, Andalas University, Padang (2011). Now the Author is a Professor and Researcher at the Faculty of Pharmacy, Andalas University, Padang. The Author also serves as Deputy Chair of Academic Affairs at the YPTIK Padang College of Pharmacy (STIFARM). The Author wrote the book "Principles of Chemical Examination" (Publisher UI-Press, 1995), translated the book "Pharmaceutical Statistics" (EGC Medical Book Publishers, 2010), and wrote "Chapter 4" in the book "Recent Research Advances in Biology Vol. 4" (International Book Publisher, India, and United Kingdom, 2020), and wrote the book "Chinese Petai (Leucaena leucocephala): Traditional Uses, Phytochemicals, and Pharmacological Activities" (Deepublish, Yogyakarta, 2021). The Author wrote "Chapter 9" in the book "Recent Research Advances in Biology Vol. 7" (International Book Publisher, India, and United Kingdom, 2021). The Author has also written articles in various international journals in various science fields, such as chemistry, biology, and pharmacy. 